\title{
Multivariate Optimization and Exploratory Analysis Applied to the Internal Standardization of Complex Matrices by Inductively Coupled Plasma Optical Emission Spectrometry
}

\author{
Roberta Eliane Santos Froes-Silva ${ }^{a *}$, Waldomiro Borges Neto $^{b}$, Clésia Cristina Nascentes $^{c}$, \\ and José Bento Borba Silva ${ }^{c}$ \\ a Departamento de Química, Universidade Federal de Ouro Preto, Campus Universitário, \\ 35400-000 Ouro Preto-MG, Brazil

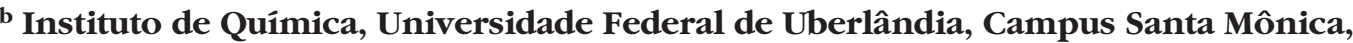 \\ PO Box 593, 38400-902, Uberlândia-MG, Brazil \\ c Departamento de Química, Instituto de Ciências Exatas, Universidade Federal de Minas Gerais, \\ Av. Antônio Carlos, 6627, Pampulha, Belo Horizonte, Minas Gerais, 31.270-901, Brazil
}

\section{INTRODUCTION}

Trace elements in complex matrices, such as biopharmaceutical drug products, environmental, geochemical, beverages, biological, and food samples, are commonly determined by various spectrometric analytical techniques (1-4). The composition of the matrix may affect the analytical signal, and consequently deteriorate its accuracy and precision. In the analysis of some environmental, food and beverage, geological, drug, and other samples, easily ionized elements (EIEs), such as $\mathrm{Na}, \mathrm{K}$, and $\mathrm{Ca}$, are generally present at high concentrations. These elements may promote a stronger interference effect. In the spectrometric analysis of complex matrices, it is common to employ analytical strategies to minimize interference effects. The pretreatment procedures of complex samples include acid digestion under conventional or microwave heating $(6,7)$, dilution with appropriate solvents (2), emulsification $(8,9)$, acid and solid phase extraction $(10,11)$, ultrasound-assisted extraction (12), and others (13). In addition to an increase in experimental time, cost of analysis, and the amount of sample required,

*Corresponding author.

E-mail: robertafroes@hotmail.com

Tel: (55) $313559-1233$

\section{ABSTRACT}

The presence of high concentrations of $\mathrm{Na}, \mathrm{K}, \mathrm{Ca}$, and $\mathrm{C}$ in complex matrices such as beverages, foods, and pharmaceutical formulations may interfere in their analysis by inductively coupled plasma optical emission spectrometry (ICP-OES). The interference is amplified when it is associated with large variations in operating conditions. Internal standardization is indicated for the repair of this interference effect. Elements that present comparable behavior in similar conditions may be used as internal standards (IS) for other elements. The behavior of 31 analytical lines in the presence of $\mathrm{Ca}, \mathrm{K}$, and $\mathrm{Na}$ (250 and $1000 \mathrm{mg} \mathrm{L}^{-1}$ ) in $8 \%$ urea, to simulate pharmaceuticals, beverages, and foods, was evaluated under different operating conditions by hierarchical cluster analysis (HCA) and principal component analysis (PCA). The HCA and PCA methods formed four element groups with similar behavior. In these groups, some elements were tested as IS from the other groups. It was possible to choose the best IS for the element groups, and the recoveries were close to $100 \%$ with simulated samples. This study amplified the possibility of selecting internal standards for the analysis of complex matrices, thus promoting better precision and accuracy of the results. some procedures risk loss of analyte, sample contamination, and poor detection. A good strategy in the analysis of complex matrices is the use of internal standardization to minimize or avoid interference effects, thus increasing precision and accuracy (14-16). Internal standards (IS) are used to allow for the identification and correction of fluctuations during analysis (17).

In inductively coupled plasma optical emission spectrometry (ICPOES) analysis, these interferences can result in an increase or decrease of the analytical signal. Carbon is just another example of an element commonly found in most complex sample matrices, particularly in foods, drugs, and biological materials, in addition to geological and environmental samples. An increase in carbon concentration may cause an increase in background radiation due to nonspecific emissions and, consequently, resulting in poor limits of detection and quantification by ICP-OES measurements. Thus, the direct introduction of a complex sample matrix into an ICP-OES may suffer interference effects.

Multivariate optimization of the experimental conditions makes direct analysis possible. However, if the traditional methods of multivariate optimization are applied for each element, model construction for each element will be necessary. Most applications require matrix 
pre-treatment, because the direct determination of trace elements in complex matrices is difficult as a result of interference effects. Biopharmaceutical drug products consist of multiple inactive ingredients, including monoclonal antibodies (mAbs), antibody drug conjugates (ADCs), protein-conjugated vaccines and others, and the excipients (4). Several kinds of excipients are used in biopharmaceutical drug products to enhance stability, control $\mathrm{pH}$, and adjust tonicity (5). The excipients are diversified, including cations (such as $\mathrm{Na}, \mathrm{K}$, and $\mathrm{Ca}$ ), anions, zwitterions (i.e., amino acids), hydrophobic surfactants, hydrophilic sugars, etc. (5).

Inductively coupled plasma optical emission spectrometry is a technique commonly used to investigate the mineral composition of complex matrices (17-20). Easily ionized elements (EIEs), such as $\mathrm{Na}$, $\mathrm{K}$, and $\mathrm{Ca}$, are generally present in high concentrations in foods, beverages, and drugs $(21,22)$. They may strongly interfere with ICP-OES analysis by either increasing or decreasing the analytical signal. Brenner et al. (21) reported that increasing the $\mathrm{Na}$ and $\mathrm{Ca}$ concentrations decreased the analytical signals of $\mathrm{Mo}, \mathrm{Co}, \mathrm{Ni}, \mathrm{Cd}, \mathrm{Be}, \mathrm{Pb}$, and $\mathrm{Zn}$ in axial and radial viewing. They also observed that the Ca effect is stronger than that of $\mathrm{Na}$ as more energy is required to dissociate the matrix in aqueous solutions with 0-1000 $\mathrm{mg} \mathrm{L}^{-1}$ of $\mathrm{Na}^{+}$and $\mathrm{Ca}^{2+}$. A single IS [Sc(II), $361.384 \mathrm{~nm}$ ] was used to compensate for this depressive effect. In_another study, Brenner et al. (22) evaluated the interference effects of $\mathrm{Ca}$ and $\mathrm{Na}$ on the atomic and ionic lines of As, $\mathrm{Be}, \mathrm{Cd}, \mathrm{Co}, \mathrm{Cr}, \mathrm{Cu}, \mathrm{Fe}, \mathrm{Li}, \mathrm{Mg}, \mathrm{Mn}$, Mo, Ni, Pb, Sb, Se, Sr, Ti, Tl, V, and $\mathrm{Zn}$ using both high and low aerosol loadings on spectral line measurements in a $0.1 \% \mathrm{Ca}$ and $\mathrm{Na}$ solution. According to the results, the limits of detection degraded 10- to 16-fold using cross-flow nebulization, and about 30-fold with ultrasonic nebulization (22). Dubuisson et al. (23) compared axial and radial ICP-OES with and without IS to compensate for the Na effects $\left(10 \mathrm{~g} \mathrm{~L}^{-1}\right)$ on accuracy. The authors obtained good efficiency with a single IS $\left(\mathrm{Ni}^{2+}\right.$ at the 231-nm line) for radial ICP-OES. The axial view mode (with or without IS) failed to provide the same quality and efficiency as that of the radial measurements with IS. Carbon is another element which is mostly found in foods, drugs, and beverages. An increase in the carbon concentration may increase the background radiation due to nonspecific emissions, consequently resulting in inferior limits of detection and quantification (24).

The application of IS is only effective if the IS and analyte behaviors are similar with respect to the interference effects and instrumental noise. Therefore, the proper selection of IS has received considerable attention. The IS may be selected by employing various methods, including a universal IS such as yttrium and scandium (25, 26). An alternative would be the base selection of the response of each analytical line tested as an IS compared to the analyte. Recovery studies of spiked concentrations and the relative standard deviation obtained with or without IS should be observed in IS applications (26).

Recently, chemometric tools have been used for choosing the best element as the internal standard (27). Grotti et al. (27) analyzed the IS efficiency in the reduction of matrix effects caused by $\mathrm{Fe}, \mathrm{Al}, \mathrm{Ca}, \mathrm{Na}$, and $\mathrm{K}$ on the analytical signals of $\mathrm{As}, \mathrm{Cd}, \mathrm{Cr}, \mathrm{Cu}, \mathrm{Mn}$, $\mathrm{Mo}, \mathrm{Ni}, \mathrm{P}, \mathrm{Pb}, \mathrm{V}$, and $\mathrm{Zn}$ in ICP-OES and the reduction of acidic effects. Optimal IS was selected based on the set of measurements supplied by the factorial design processed by principal component analysis (PCA). By analogous selection of the IS, Pan et al. (28) developed a method to determine $\mathrm{As}, \mathrm{Sb}$, and $\mathrm{Se}$ in synthetic digested plant- and food-based solutions.

The following study evaluates different elements as internal standards based on their similarity of analytical lines obtained by ICP-OES analysis and using multivariate optimization and exploratory analysis.

\section{EXPERIMENTAL}

\section{Instrumental Operating Conditions}

Measurements were performed using an Optima 2000 DV ICPOES, dual view (PerkinElmer, Inc., Shelton, CT, USA) with axial (AXICP-OES) and radial (RD-ICP-OES) configurations. The radio frequency source $(40 \mathrm{MHz})$ provided a power of $0.75-1.5 \mathrm{~kW}$. A 79-nm ${ }^{-1}$ line Echelle grating, solid-state detector, cross-flow nebulizer, coupled with a double-pass Scott-type spray chamber, and interface shear gas were used. The sample injection system was automated using an AS 90 Plus autosampler (PerkinElmer). The remaining operating conditions are presented in Table I, and the analytical lines and their properties in Table II.

\section{Reagents, Solutions, and Materials}

Analytical grade $\mathrm{Na}, \mathrm{K}$, and $\mathrm{Ca}$ salts $\left(\mathrm{NaCl}, \mathrm{KCl}\right.$, and $\mathrm{CaCl}_{2}$ from VETEC, São Paulo, Brazil) were used to obtain a $10 \mathrm{~g} \mathrm{~L}^{-1}$ intermediate solution of each element. Standard solutions, containing $1000 \mathrm{mg}$ $\mathrm{L}^{-1}$ of $\mathrm{Al}, \mathrm{As}, \mathrm{Ba}, \mathrm{Be}, \mathrm{Cd}, \mathrm{Cr}, \mathrm{Cu}, \mathrm{Fe}$, $\mathrm{Hg}, \mathrm{Ir}, \mathrm{Li}, \mathrm{Mg}, \mathrm{Mn}, \mathrm{Mo}, \mathrm{Ni}, \mathrm{Pb}, \mathrm{Pt}$, $\mathrm{Rb}, \mathrm{Rh}, \mathrm{Ru}, \mathrm{Sb}, \mathrm{Se}, \mathrm{Sn}, \mathrm{Sr}, \mathrm{Ti}, \mathrm{Tl}, \mathrm{V}$, W, Y, Zn, and Zr (ICP Standard, Certipur ${ }^{\circledR}$, Merck. Darmstadt, Germany) were used for this study. A multi-element intermediate solution, containing $100 \mathrm{mg} \mathrm{L}^{-1}$ of the above-mentioned elements in 2\% (v/v) $\mathrm{HNO}_{3}$ (from 70\% VETEC, São Paulo, Brazil), was previously prepared and used to obtain the 


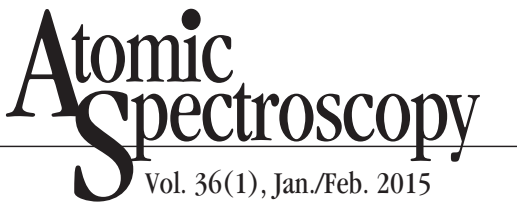

TABLE I

ICP-OES Operating Conditions

\begin{tabular}{ll}
\hline Parameters & \\
\hline Auxiliary gas flow rate & $0.2 \mathrm{~L} \mathrm{~min}^{-1}$ \\
Plasma gas flow rate & $15 \mathrm{~L} \mathrm{~min}^{-1}$ \\
Injector tube diameter & $2.0 \mathrm{~mm}$ \\
View & Axial \\
Interface & Shear gas \\
Sample flow rate & $1.0-1.5 \mathrm{~mL} \mathrm{~min}$ \\
Applied power & $1.1-1.5 \mathrm{~kW}$ \\
Nebulization gas flow rate & $0.4-1.1 \mathrm{~L} \mathrm{~min}^{-1}$ \\
\hline
\end{tabular}

reference solutions. Urea (QUIMEX, São Paulo, Brazil) was used to prepare a carbon reference solution. Deionized water from a Milli-Q ${ }^{\circledR}$ system (Millipore Corporation, Bedford, MA, USA) was used to prepare all solutions.

Synthetic reference solutions, simulating several beverages, some pharmaceutical products and foods, were prepared with 250 and 1000 $\mathrm{mg} \mathrm{L}^{-1} \mathrm{Na}, \mathrm{K}$, and Ca, $8 \%(\mathrm{w} / \mathrm{v})$ urea, and $1.0 \mathrm{mg} \mathrm{L}^{-1} \mathrm{Al}, \mathrm{As}, \mathrm{Ba}, \mathrm{Be}$, $\mathrm{Cd}, \mathrm{Cr}, \mathrm{Cu}, \mathrm{Fe}, \mathrm{Hg}$, Ir, Li, Mg, Mn, $\mathrm{Mo}, \mathrm{Ni}, \mathrm{Pb}, \mathrm{Pt}, \mathrm{Rb}, \mathrm{Rh}, \mathrm{Ru}, \mathrm{Sb}, \mathrm{Se}$, $\mathrm{Sn}, \mathrm{Sr}, \mathrm{Ti}, \mathrm{Tl}, \mathrm{V}, \mathrm{W}, \mathrm{Y}, \mathrm{Zn}$, and $\mathrm{Zr}$. These solutions were used in the multivariate optimization experiments and recovery studies.

\section{Data Collection and Treatment}

Multivariate optimization is an appropriate data collection method because it allows for evaluation of the responses to many variables and their interactions $(29,30)$. A $2^{3}$ factorial design was employed to obtain the response of 31 analytical lines in a synthetic reference solution. The behavior of the analytical lines, submitted to several different operating conditions, were evaluated. The factors and levels that were employed included nebulization gas flow rate $\left(0.4-1.1 \mathrm{~L} \mathrm{~min}^{-1}\right)$, applied power (1.1-1.5 kW), and sample flow rate $\left(1.0-1.5 \mathrm{~mL} \mathrm{~min}^{-1}\right)$. The resulting responses were evaluated by exploratory methods of analysis known as Hierarchical
Cluster Analysis (HCA) and Principal Component Analysis (PCA). The same methodology was used by Penteado et al. (31) in the optimization of solid-phase microextraction conditions for gas chromatographymass spectrometry analysis of linear alkylbenzenes in detergents. The authors evaluated the operating conditions and determined the optimum analysis conditions.

Recovery studies were used to evaluate the accuracy and precision of the applied method to select the IS for each analyte.

\section{RESULTS AND DISCUSSION}

\section{Experimental Consideration}

Internal standardization (IS) efficiency depends on the operating conditions. Elements that show similar behavior when submitted to different experimental conditions may be employed as IS for a group of elements that also exhibit similar behavior under the same conditions $(14,19,20,26)$. The behavior of 31 analytical lines in the presence of high $\mathrm{Na}, \mathrm{K}, \mathrm{Ca}$, and $\mathrm{C}$ concentrations, under different experimental conditions, was evaluated. Table III lists the experimental and analytical responses of each element according to this design. The matrix data with the analytical signal, obtained by a $2^{3}$ factorial design, were evaluated by exploratory analysis.
TABLE II

Analytical Lines, Respective Wavelengths, and Ionization Energy

\begin{tabular}{|c|c|c|}
\hline Element & $\begin{array}{l}\text { Wavelength } \\
(\mathrm{nm})\end{array}$ & $\begin{array}{l}\text { Ionization } \\
\text { Energy }(\mathrm{eV})\end{array}$ \\
\hline $\mathrm{Al} \mathrm{I}$ & 396.153 & 5.99 \\
\hline As I & 193.696 & 9.81 \\
\hline Ba II & 493.408 & 5.21 \\
\hline Be II & 313.042 & 9.32 \\
\hline Cd II & 214.440 & 8.99 \\
\hline $\mathrm{Cr}$ II & 267.716 & 6.77 \\
\hline $\mathrm{Cu} \mathrm{I}$ & 324.752 & 7.73 \\
\hline Fe II & 238.204 & 7.87 \\
\hline $\mathrm{Hg} \mathrm{I}$ & 253.652 & 10.4 \\
\hline Ir II & 224.268 & 9.00 \\
\hline Li I & 610.362 & 5.39 \\
\hline Mg II & 280.271 & 7.65 \\
\hline Mn II & 257.610 & 7.44 \\
\hline Mo II & 202.031 & 7.1 \\
\hline Ni II & 221.648 & 7.64 \\
\hline $\mathrm{Pb}$ II & 220.353 & 7.42 \\
\hline Pt I & 265.945 & 9.00 \\
\hline $\mathrm{Rb} I$ & 780.023 & 4.18 \\
\hline Rh II & 343.489 & 7.45 \\
\hline Ru II & 240.272 & 7.37 \\
\hline Sb I & 206.836 & 8.64 \\
\hline Se I & 196.026 & 9.75 \\
\hline Sn I & 235.485 & 7.34 \\
\hline Sr II & 407.771 & 5.70 \\
\hline Ti II & 334.940 & 6.82 \\
\hline Tl I & 276.787 & 6.11 \\
\hline V II & 292.464 & 6.74 \\
\hline W II & 207.912 & 7.98 \\
\hline Y II & 371.029 & 6.38 \\
\hline Zn II & 213.857 & 9.39 \\
\hline $\mathrm{Zr}$ II & 343.823 & 6.84 \\
\hline
\end{tabular}

The dendrogram obtained by hierarchical cluster analysis (HCA) is shown in Figure 1. The 31 analytical lines were separated into four groups. Variations in the experimental conditions are grouped by analytical lines according to line type: either ionic or atomic, and according to potential energy values (excitation for atomic lines and sum of 
TABLE III

$2^{3}$ Factorial Design Factors, Levels, and Conditions

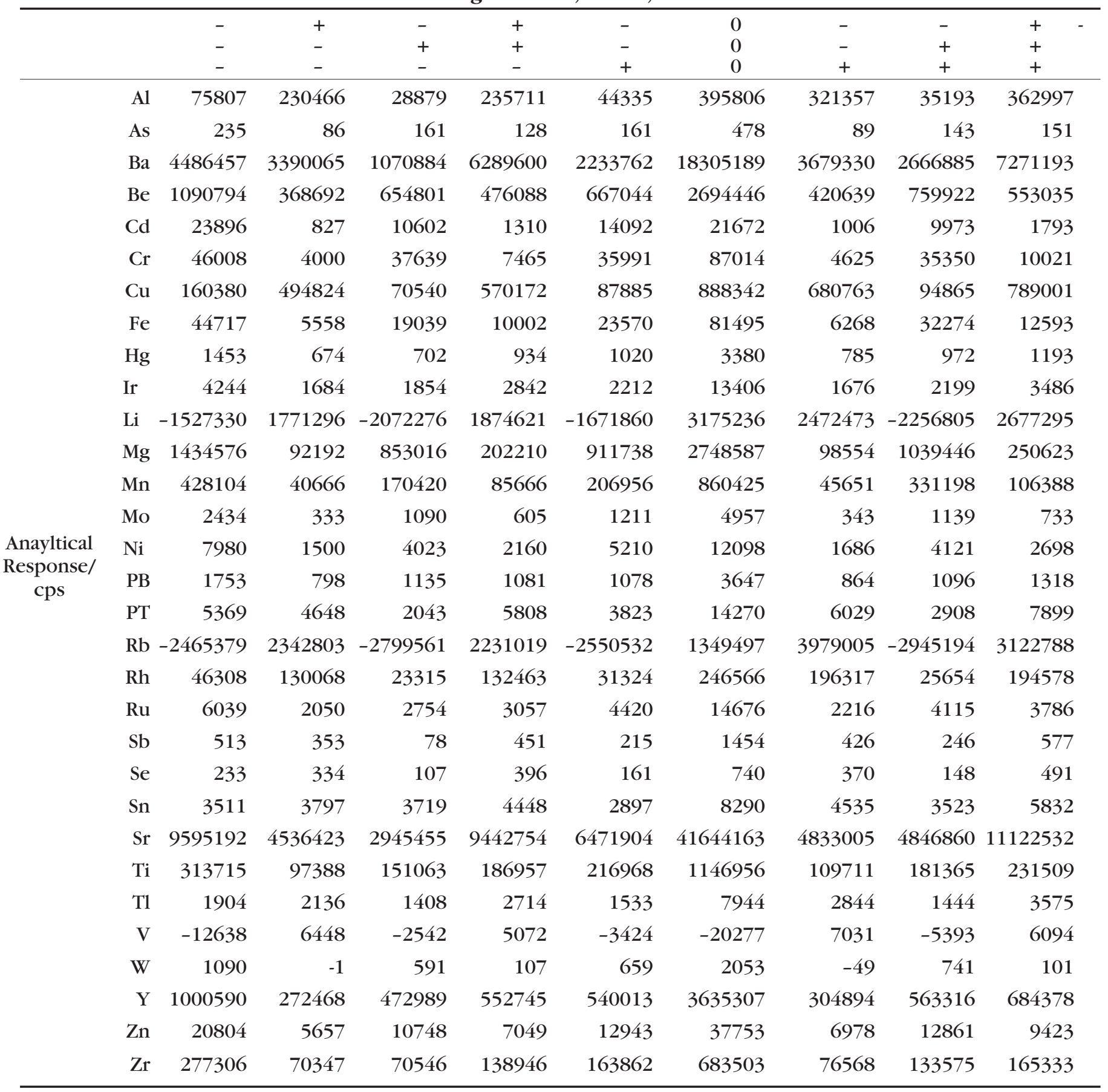

\begin{tabular}{lll}
\hline$(-)$ & $(+)$ & Variables \\
0.4 & 1.1 & Nebulization gas flow rate $\left(\mathrm{L} \mathrm{min}^{-1}\right)$ \\
1.1 & 1.5 & Applied power $(\mathrm{kW})$ \\
1.0 & 1.5 & Sample flow rate $\left(\mathrm{mL} \mathrm{min}^{-1}\right)$
\end{tabular}




\section{A $_{\text {Spectroscopy }}^{\text {pectros }}$ \\ 1 Vol. 36(1), Jan./Feb. 2015}

excitation and first ionization for ionic lines). The first group was composed of the atomic lines $\mathrm{Al}$, $\mathrm{Cu}, \mathrm{Li}, \mathrm{Rh}$, and $\mathrm{Rb}$ with intermediate and low potential energy values, with the exception of Rh, which has an intermediate potential energy ionic line. The second group was formed by $\mathrm{Cd}, \mathrm{Fe}, \mathrm{Mn}$, $\mathrm{Zn}, \mathrm{Mo}, \mathrm{Ni}, \mathrm{Cr}, \mathrm{Mg}$, and $\mathrm{W}$, which has high potential energy ionic lines. Cadmium was considered in this group, even though it was somewhat dissimilar from the others. The third group consisted of $\mathrm{Pb}, \mathrm{As}, \mathrm{Ru}, \mathrm{Be}, \mathrm{Hg}, \mathrm{Zr}$, Ti, Y, Ir, and $\mathrm{Sr}$, which has intermediate and high potential energy ionic lines, with the exception of As and $\mathrm{Hg}$, which possess high potential energy atomic lines. The fourth group of elements was formed by the atomic lines of $\mathrm{Sn}, \mathrm{Se}, \mathrm{Sb}, \mathrm{Ba}, \mathrm{Pt}$, and $\mathrm{Tl}$, which has intermediate and high potential energy, except for Ba, which has a low potential energy ionic line.

The first three principal components explain $97.3 \%$ of the total variance. The object scores and variable loadings for these components are plotted in Figure 2. The same groups of elements obtained in HCA were observed in PCA. PC1, which represents $80 \%$ of the total variance, separates the ionic lines from the atomic lines.

\section{IS Selection per Group}

Theoretically, the best IS for one element is that which shows the same behavior under identical conditions. Each element group that was created was evaluated separately. Yttrium was used as a universal IS $(11,28)$ and was tested for all analyzed elements. The IS efficiency was evaluated via recovery value of the solutions spiked with $1.0 \mathrm{mg} \mathrm{L}^{-1}$ of $\mathrm{Al}, \mathrm{As}, \mathrm{Ba}, \mathrm{Be}, \mathrm{Cd}$, $\mathrm{Cr}, \mathrm{Cu}, \mathrm{Fe}, \mathrm{Hg}$, Ir, Li, Mg, Mn, Mo, $\mathrm{Ni}, \mathrm{Pb}, \mathrm{Pt}, \mathrm{Rb}, \mathrm{Rh}, \mathrm{Ru}, \mathrm{Sb}, \mathrm{Se}, \mathrm{Sn}, \mathrm{Sr}$, Ti, Tl, V, W, Y, Zn, and $\mathrm{Zr}$ in two interference levels $\left(250 \mathrm{mg} \mathrm{L}^{-1}\right.$ and

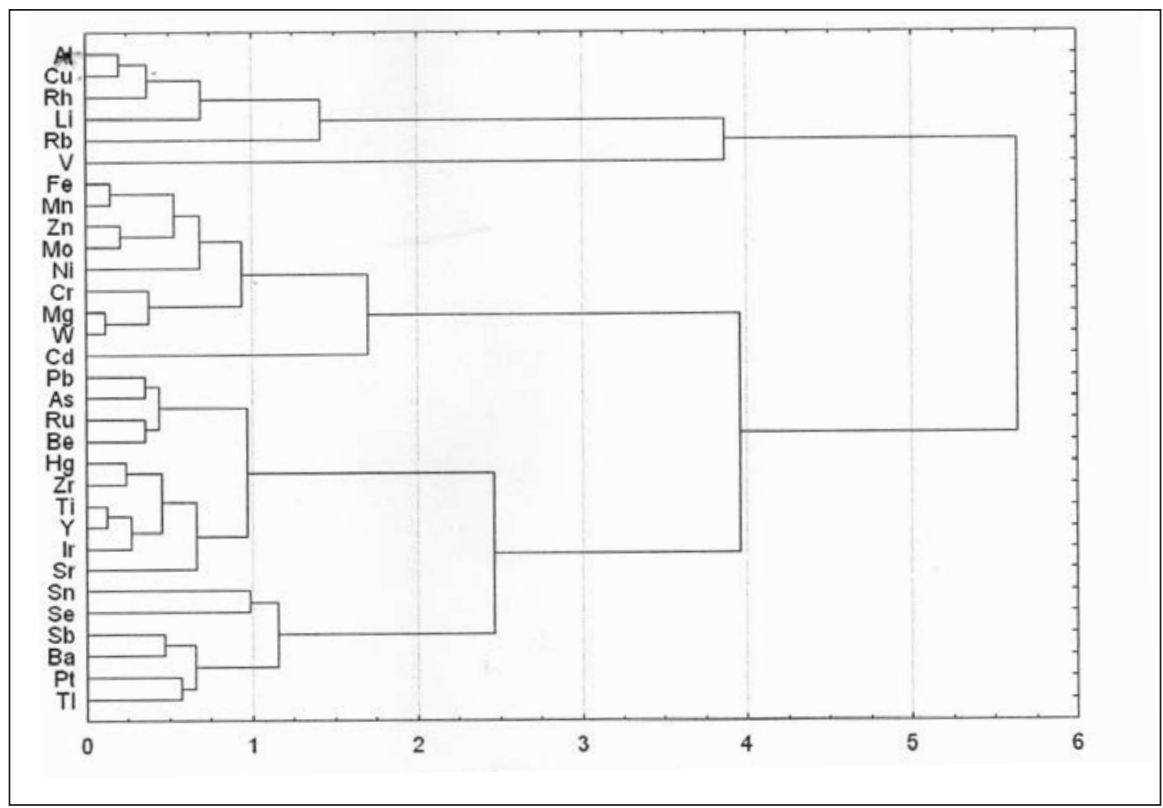

Fig. 1. Dendogram of analytical signal of the elements.

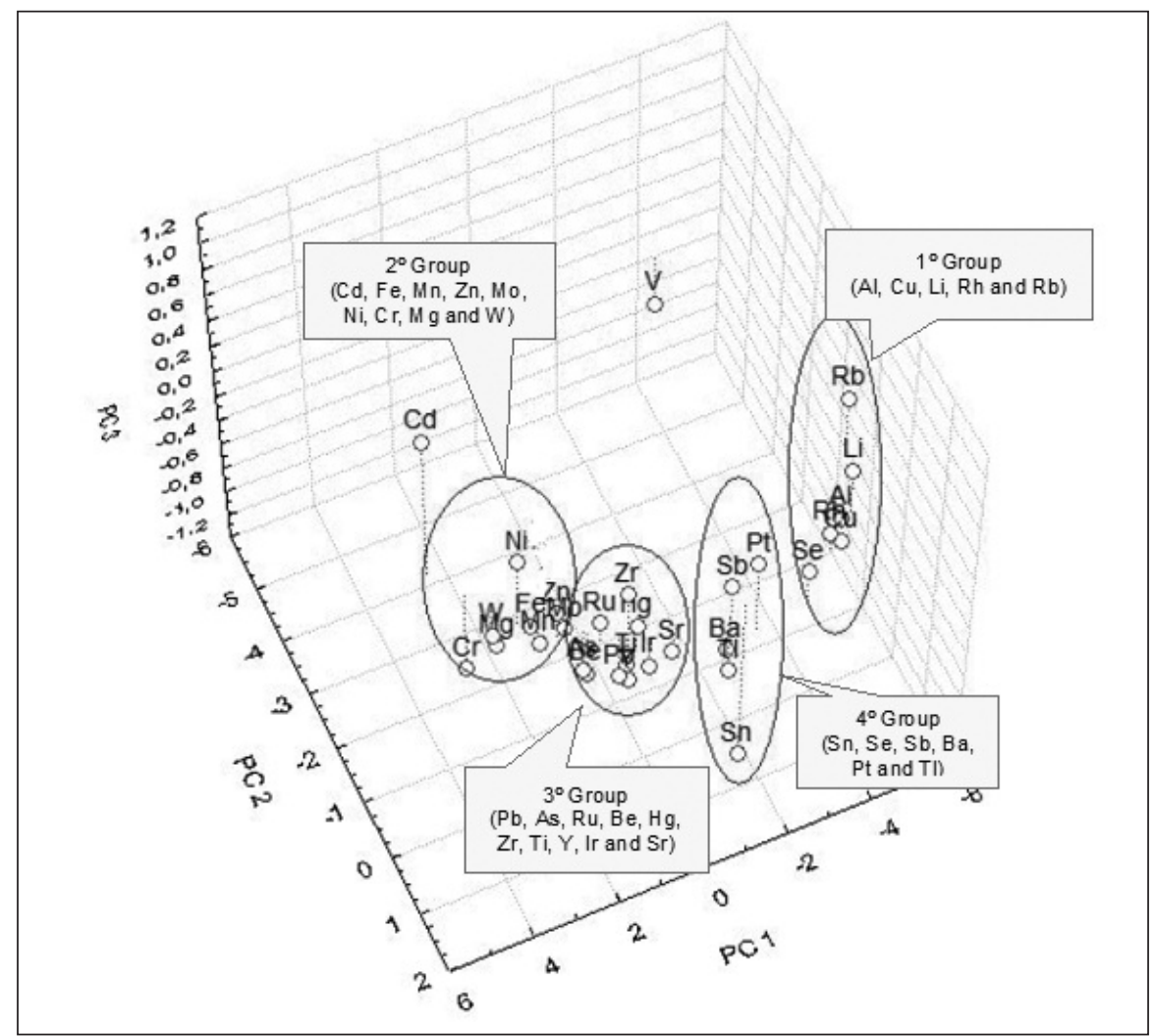

Fig. 2. Score plots of elements in synthetic sample. 

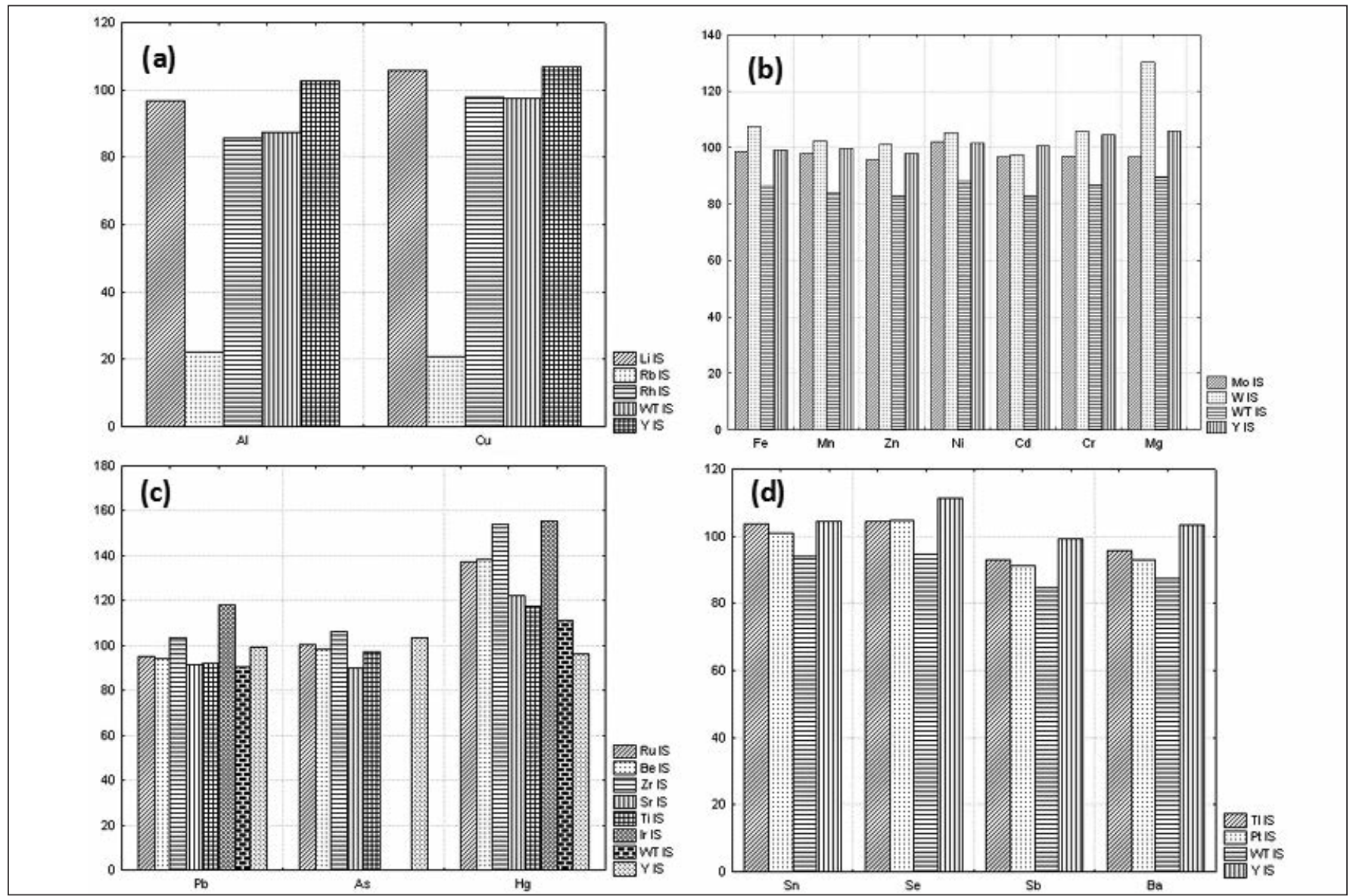

Fig. $3(a, b, c, d)$. Recovery study for the internal standardization in element groups found in HCA and PCA with 250.0 mg $L^{-1}$ spiked solution.

$1000 \mathrm{mg} \mathrm{L}^{-1}$ of $\mathrm{K}, \mathrm{Na}$, and $\mathrm{Ca}$ in $8 \%$ urea). In accordance with scientific literature (32), the acceptable recovery values should be between 80 and $120 \%$. The best IS for each group were the recoveries considered closest to $100 \%$ of the spiked values. The results obtained are shown in Figure $3\left(250 \mathrm{mg} \mathrm{L}^{-1}\right)$ and Figure $4\left(1000 \mathrm{mg} \mathrm{L}^{-1}\right)$.

The analytes measured in each group were elements with the greatest significance for food, drug, and beverage analysis. In the first group, $\mathrm{Li}, \mathrm{Rh}$, and $\mathrm{Rb}$ were evaluated as IS for $\mathrm{Al}$ and $\mathrm{Cu}$. In the presence of $250 \mathrm{mg} \mathrm{L}^{-1}$ of concomitants (Figure 3a), Y was the best IS for Al, with a recovery value of $102.6 \%$. For $\mathrm{Cu}$, the best IS was Rh, with a
$97.8 \%$ recovery value. When the concentration of concomitants was $1000 \mathrm{mg} \mathrm{L}^{-1}$ (Figure 4a), the best IS for $\mathrm{Al}$ was $\mathrm{Li}(87.4 \%)$, and for $\mathrm{Cu}$, it was Rh (94.4\%).

In the second group (Cd, Fe, Mn, $\mathrm{Zn}, \mathrm{Mo}, \mathrm{Ni}, \mathrm{Cr}, \mathrm{Mg}$, and W), Mo, W, and $\mathrm{Y}$ were evaluated as IS. For 250 $\mathrm{mg} \mathrm{L}^{-1}$ of concomitants (Figure $3 \mathrm{~b}$ ), $\mathrm{Y}$ was the best IS for almost every element, excluding Zn (W 101.0\%) and $\mathrm{Cr}$ (Mo 97.0\%). The obtained recovery values were: Fe $99.3 \%$, Mn $99.7 \%$, Ni 101.5\%, Cd 100.5\%, and $\mathrm{Mg} 105.7 \%$. For $1000 \mathrm{mg} \mathrm{L}^{-1}$ of concomitants (Figure 4b), Y remained the best IS for almost every element with the following percent recovery values: Mn 95.4\%, Zn 95.8\%, Ni $96.3 \%$, Cd 92.5\%, Cr 100.7\%, and
$\mathrm{Mg}$ 103.4\%. For Fe, under the same conditions, the best IS was W at $107.2 \%$ recovery.

In examining the third group, $\mathrm{Ru}, \mathrm{Be}, \mathrm{Zr}$, Ti, Ir, and Sr were evaluated as IS for $\mathrm{Pb}, \mathrm{As}$, and $\mathrm{Hg}$. For $250 \mathrm{mg} \mathrm{L}^{-1}$ of concomitants (Figure $3 \mathrm{c}), \mathrm{Y}$ was the best IS for $\mathrm{Pb}$ (99.2\%) and $\mathrm{Hg}$ (96.5\%). For As, a $100.4 \%$ recovery was obtained when Ru was employed as IS, and $103 \%$ with Y as IS. For higher concentrations of concomitants (1000 $\mathrm{mg} \mathrm{L}^{-1}$, Figure 4c), Ru was the best IS for $\mathrm{Pb}(97.2 \%), \mathrm{Zr}$ for As (101.2\%), and Y for $\mathrm{Hg}$ (92.9\%). However, the recovery values for $\mathrm{Pb}$ and As with $\mathrm{Y}$ as IS was 93\% and $106 \%$, respectively. Platinum, thallium, and yttrium were tested as IS 


\section{Atomic Apectroscopy \\ Vol. 36(1), Jan./Feb. 2015}

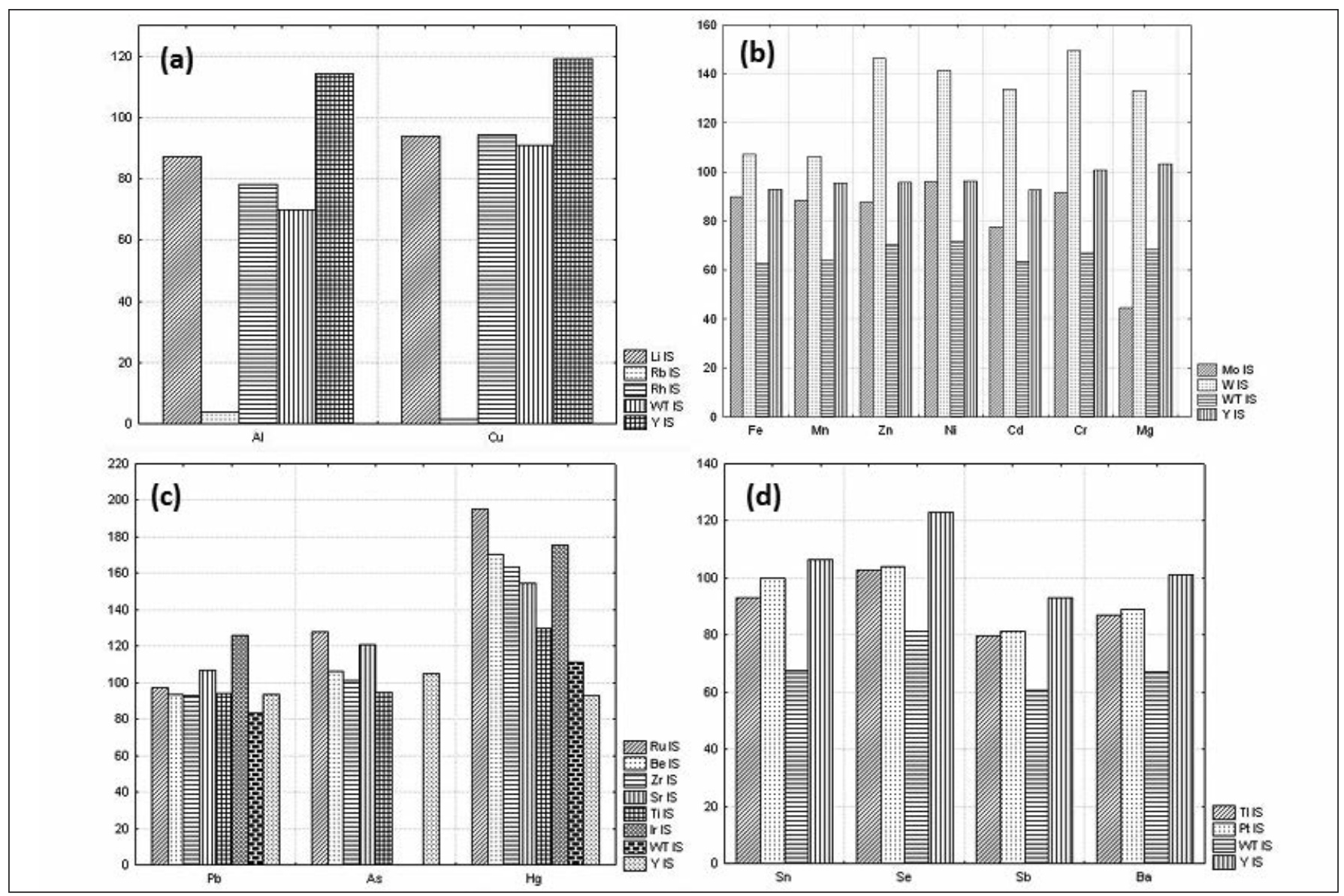

Fig. $4(a, b, c, d)$. Recovery study for the internal standardization in element groups found in HCA and PCA with 1000.0 mg $L^{-1}$ spiked solution.

for the group formed by $\mathrm{Sn}, \mathrm{Se}, \mathrm{Sb}$, $\mathrm{Ba}, \mathrm{Pt}$, and $\mathrm{Tl}$ in concomitant concentrations of 250 and $1000 \mathrm{mg} \mathrm{L}^{-1}$ (Figures $3 \mathrm{~d}$ and $4 \mathrm{~d}$ ). The best IS for Sn was Pt, with $100.8 \%$ and $99.9 \%$ recoveries, respectively. For Se, the best IS was Tl, with $104.3 \%$ and $102.7 \%$ recoveries, respectively. $\mathrm{Y}$ was the best IS for $\mathrm{Sb}$ and $\mathrm{Ba}$ in $250 \mathrm{mg} \mathrm{L}^{-1}$ of concomitants, with $99.2 \%$ and $103.5 \%$ recoveries, respectively, and $93.1 \%$ and $101.3 \%$ for $1000 \mathrm{mg} \mathrm{L}^{-1}$ of concomitants, respectively. For most elements, more than one reference line yielded good recovery values according to some studies $(33,34)$, which ranged between $80 \%$ and $120 \%$. Therefore, the selection of an appropriate IS depends on the investigative interest, the sample type, and the absence of possible IS in the matrix composition.

\section{CONCLUSION}

The use of exploratory analysis methods associated with multivariate optimization allowed for the evaluation of 31 analytical lines in a synthetic complex matrix subjected to different experimental conditions and groupings according to the similarity of their behavior. The best internal standard (IS) was successfully selected according to the behavior of similarity and analytical interest of each element in each group, yielding recovery values close to $100 \%$. In addition to the universal internal standards, any analytical line in the group of simi- larity may be used as an internal standard, depending on the presence of the element in the sample, the analytical interest, and the recovery assay of the potential IS. In this study, we observed that at concentrations of $250 \mathrm{mg} \mathrm{L}^{-1}$ of interference studied, Rh was the best IS for $\mathrm{Cu}$; Ru for As; Tl for Se; $\mathrm{Pt}$ for $\mathrm{Sn}$; and $\mathrm{Y}$ for $\mathrm{Al}, \mathrm{Pb}, \mathrm{Hg}, \mathrm{Sb}$, and $\mathrm{Ba}$. For the concentrations of the interferents at $1000 \mathrm{mg} \mathrm{L}^{-1}, \mathrm{Li}$ was the best IS for $\mathrm{Al}$; $\mathrm{Rh}$ for $\mathrm{Cu}$; $\mathrm{W}$ for $\mathrm{Fe}$; $\mathrm{Ru}$ for $\mathrm{Pb}$; $\mathrm{Zr}$ for $\mathrm{As}$; and $\mathrm{Y}$ for $\mathrm{Hg}$. 


\section{ACKNOWLEDGMENT}

The authors are grateful for the financial support and scholarships from the Conselho Nacional de Pesquisa e Desenvolvimento (CNPq) and Fundação de Amparo à Pesquisa do Estado de Minas Gerais (FAPEMIG). C.C. Nascentes and J.B.B. Silva are grateful to $\mathrm{CNPq}$ for the research grant.

Received August 19, 2014.

\section{REFERENCES}

1. M.N. Reyes and R.C. Campos, Talanta 70, 929 (2006).

2. A. Economou, Trends in Anal. Chem. 24, 416 (2005).

3. I. De Schrijver, M. Aramendia, L. Vincze, M. Resano, A. Dumoulin, and F. Vanhaecke. Spectrochim. Acta Part B 27, 1185 (2007).

4. Y. He, O.V. Friese, M.R. Schlittler, Q Wang, X. Yang, L.A. Bass, and M.T. Jones, J. Chromatogr. A 1262, 122 (2012).

5. M.F. Powel, T. Nguyen, and L. Baloian, J. Pharm. Sci. Technol. 52, 238 (1998).

6 L. Sanchez-Prado, C. Garcia-Jares, and M. Lompart. J. Chromatog. A 1217 , 2390 (2010).

7. A. Otero-Pazos, J. Perez-Iglesias, J.M. Fernandez-Solis, J.M. CastroRomero, E. Gonzalez-Soto, and V. Gonzalez-Rodriguez, Anal. Letters 41, 2503 (2008).

8. Wang T and Wu XJXJ. Direct determination of metals in organics by inductively coupled plasma atomic emission spectrometry in aqueous matrices. J. Pharm. Biomed. Anal. 33: 639, (2003).

9. C. Pizarro, C. Sàenz-Gonzàlez, N. Pèrez-del-Notario andJ.M. Gonzàlez-Sàiz. J. Chromatography A 1244, 37, (2012).

10. M. Tuzen, E. Melek and M. Soylak. J. Haz. Mater. 159, 335, (2008).

11. Y. Li, Y.F. Huang, Y. Jiang, B.I. Tian, F. Han and X.P. Yan. Anal. Chim. Acta 692, 42, (2011).
12. J.L. Tadeo, C. Sànchez-Brunete, B. Albero and A.I. Gàrcia-Varcàrcel. J. Chromatography A 1217, 2415, (2010).

13. P.A. Mello, J.S.F. Pereira, M.F. Mesko, J.S. Barin and E.M.M. Flores. Anal. Chim. Acta 746, 15, (2012).

14. R.E.S. Froes, N.O.C. Silva, R.L.P. Naveira, J.C.J. Silva, V.S.T. Ciminelli, C.C. Windmoller and J.B.B. Silva. At. Spectrom. 28, 8, (2007).

15. H.J. Finley-Jones, J.L. Molloy and J.A .Holcombe. J. Anal. At. Spectrom. 23, 1214, (2008).

16. E.C. Ferreira, S.H.B.G. Rodrigues, M.M.C. Ferreira, J.A. Nóbrega and A.R.A. Nogueira. Ecletica Quim. 27, 77, (2002).

17. M. Grotti, E. Magi and R. Leardi. J. Anal. At. Spectrom. 18, 274 , (2003).

18. A. Krejcová, T. Cernohorský and D. Meixner. Food Chem. 105, 242, (2007).

19. R.E.S. Froes, W. Borges Neto, N.O.C. Silva, R.L.P. Naveira, C.C. Nascentes and J.B.B. Silva. Microchem. J. 82, 68, (2009).

20. R.E.S. Froes, W. Borges Neto, N.O.C. Silva, R.L.P. Naveira, C.C. Nascentes and J.B.B. Silva. Spectrochim. Acta Part B 64, 619, (2009).

21. I.B. Brenner, M. Zischka, B. Maichin and G.G. Knapp. J. Anal. At. Spectrom. 13, 1257, (1998).

22. I.B. Brenner, A. Zander, M. Cole and A. Wiseman. J. Anal. At. Spectrom. 12, 897, (1997).

23. C. Dubuisson, E. Poussel and J.M Mermet. J. Anal. At. Spectrom. 13, 265, (1998).

24. F.V. Silva, C.L. Trevisan, C.S. Silva, A.R.A. Nogueira and J.A. Nóbrega. Spectrochim. Acta Part B 57, 1905, (2002).

25. J.L. Todoli, V. Hernandis, L. Gras and J. Mora. J. Anal. At. Spectrom. 17, 142, (2002).

26. P.R.M. Correia, P.V. Oliveira, J.A.G. Neto and J.A. Nóbrega. J. Anal. At. Spectrom. 19, 917, (2004).

27. M. Grotti and R. Franche. J. Anal. At. Spectrom. 18, 1192, (2003).
28. F. Pan and J.F. Tyson. J. Anal. At. Spectrom. 22, 377, (2007).

29. R.E. Bruns, B. Barros Neto and I.S Scarminio. Como fazer experimentos: pesquisa e desenvolvimento na ciência e na indústria. Ed. Unicamp, Campinas, São Paulo, 2001.

30. D.L. Massart, B.G.M. Vandeginste, L.M.C. Buydens, S. De Jong, P.J. Lewin and J. Smeyers-Verbeke. Handbook of Chemometrics and Qualimetrics: Part B, Elsevier, Amsterdam, German, 1998.

31. J.C. Penteado, R.E. Bruns and L.R.F. Carvalho. Anal. Chim. Acta 562, 152, (2006).

32. Environmental Protection Agency EPA, Guidance for Methods Development and Methods Validation for the RCRA Program SW-846 Methods, 1992.

33. M.. Zuluaga, A. Alonso-Olazabal, X. Murelaga and L.A. Ortega. Microchem. J. 99, 443, (2011).

34. S. Ma, G.M. Turino, T. Hayashi, H. Yanuma, T. Usuki and Y.Y. Ling. Anal. Biochem. 440, 158, (2013).

35. Z. Han, Y. Zheng, L. Luan, Y. Ren and Y. Wu. J. Chromatography A 1217, 4365, (2010). 